\title{
Interleukin-1 $\beta$ and cathepsin D modulate formation of the terminal complement complex in cultured human disc tissue
}

\author{
Graciosa Q. Teixeira ${ }^{1}$ (D) Zhiyao Yong $^{1} \cdot$ Amelie Kuhn $^{2} \cdot$ Jana Riegger $^{2} \cdot$ Raquel M. Goncalves $^{1,3,4,5} \cdot$ Michael Ruf $^{6}$. \\ Uwe M. Mauer ${ }^{7} \cdot$ Markus Huber-Lang $^{8} \cdot$ Anita Ignatius $^{1} \cdot$ Rolf E. Brenner $^{5} \cdot$ Cornelia Neidlinger-Wilke $^{1}$
}

Received: 11 March 2021 / Revised: 11 May 2021 / Accepted: 14 June 2021 / Published online: 24 June 2021

(c) The Author(s) 2021

\begin{abstract}
Purpose Formation of terminal complement complex (TCC), a downstream complement system activation product inducing inflammatory processes and cell lysis, has been identified in degenerated discs. However, it remains unclear which molecular factors regulate complement activation during disc degeneration (DD). This study investigated a possible involvement of the pro-inflammatory cytokine interleukin-1 $\beta$ (IL-1 $\beta$ ) and the lysosomal protease cathepsin D (CTSD).

Methods Disc biopsies were collected from patients suffering from DD $(n=43)$ and adolescent idiopathic scoliosis (AIS, $n=13$ ). Standardized tissue punches and isolated cells from nucleus pulposus (NP), annulus fibrosus (AF) and endplate (EP) were stimulated with 5\% human serum (HS) alone or in combination with IL-1 $\beta$, CTSD or zymosan. TCC formation and modulation by the complement regulatory proteins CD46, CD55 and CD59 were analysed.

Results In DD tissue cultures, IL- $1 \beta$ stimulation decreased the percentage of TCC + cells in AF and EP $(P<0.05)$, whereas CTSD stimulation significantly increased TCC deposition in NP $(P<0.01)$ and zymosan in EP $(P<0.05)$. Overall, the expression of CD46, CD55 and CD59 significantly increased in all isolated cells during culture $(P<0.05)$. Moreover, cellular TCC deposition was HS concentration dependent but unaffected by IL-1 $\beta$, CTSD or zymosan.

Conclusion These results suggest a functional relevance of IL-1 $\beta$ and CTSD in modulating TCC formation in DD, with differences between tissue regions. Although strong TCC deposition may represent a degeneration-associated event, IL-1 $\beta$ may inhibit it. In contrast, TCC formation was shown to be triggered by CTSD, indicating a multifunctional involvement in disc pathophysiology.
\end{abstract}

Keywords Back pain · Intervertebral disc degeneration · Complement system activation · Innate immunity · Inflammation

\section{Introduction}

Intervertebral disc (IVD) degeneration is perceived as the major cause of back pain [1]. The integrity of the IVD is dependent on the balance between anabolic and catabolic

Graciosa Q. Teixeira

graciosa.teixeira@uni-ulm.de

1 Institute of Orthopaedic Research and Biomechanics, Trauma Research Centre, Ulm University, Ulm, Germany

2 Division for Biochemistry of Joint and Connective Tissue Diseases, Department of Orthopedics, Ulm University, Ulm, Germany

3 Instituto de Investigação e Inovação em Saúde (i3S), Universidade do Porto, Porto, Portugal

4 Instituto de Engenharia Biomédica (INEB), Universidade do Porto, Porto, Portugal events [2,3]. The IVD is defined as an immune-privileged tissue, particularly the nucleus pulposus (NP), but once the physiological barrier is disrupted, it can trigger an autoimmune response against specific proteins. Immunoglobulins against aggrecan, and collagen types I, II and V have been

5 Instituto de Ciências Biomédicas Abel Salazar (ICBAS), Universidade do Porto, Porto, Portugal

6 Center for Spine Surgery, Orthopedics, and Traumatology, SRH-Klinikum Karlsbad-Langensteinbach, Karlsbad, Germany

7 Department of Neurosurgery, German Armed Forces Hospital, Ulm, Germany

8 Institute of Clinical and Experimental Trauma Immunology, University Hospital Ulm, Ulm, Germany 
identified in degenerated IVDs [4]; however, this has undergone limited investigation.

IVD degeneration is characterized by a catabolic cell phenotype, with matrix degeneration, pro-inflammatory response, senescence and apoptosis [5, 6]. Matrix degeneration is mainly driven by specific enzymes including metalloproteinases and cathepsins, such as cathepsin D (CTSD) [7]. Moreover, the inflammatory response comprises an increased production of soluble mediators, such as interleukin (IL)-1 $\beta$, and increased recruitment of immune cells [8-10]. The complement system is a crucial arm of fluidphase innate immunity and our body's first line of defence. It modulates and amplifies inflammation and can also significantly contribute to inflammation-mediated tissue damage [11]. Deposition of the terminal complement complex (TCC), the final complement activation product, can act as an inflammatory trigger and inducer of cell lysis [12]. In regard to IVD pathophysiology, TCC has been identified to exhibit a distinct pattern of tissue deposition [13, 14]. Recently, a positive correlation between TCC formation and the degree of IVD degeneration in human tissue has been reported, indicating an impact of the TCC in IVD degeneration [14]. Yet, pathogenetic processes of complement involvement in the development and progression of IVD degeneration remain to be elucidated. Furthermore, little is known about complement system regulation by IVD cells. However, we have recently observed that CD59 (protectin), a membrane-bound protein known to control TCC formation [15], was likewise increased in degenerated human discs [14].

We therefore hypothesize that TCC deposition plays a role in the pathomechanism of disc degeneration and can be modulated by pathogenetically relevant factors, as well as cellular complement regulators (CRegs) thereof. To address this hypothesis, TCC deposition and CRegs expression on disc cells were investigated in vitro in degenerated IVD tissue and expanded cell cultures of annulus fibrosus (AF), nucleus pulposus (NP) and endplate (EP).

\section{Methods}

\section{Sample collection}

IVD tissue biopsies were collected from patients submitted to lumbar spine surgery as previously described [14]. A total of 13 patients were diagnosed with adolescent idiopathic scoliosis (AIS donors, 10 females/ 3 males, average age: $17 \pm 5$ years, age range: $13-34$ years) and 43 with disc degeneration (DD donors, 26 females/17 males, average age: $57 \pm 14$ years, age range: $20-82$ years). Detailed patient information is provided in Supplemental Table S1.

\section{Sample processing and tissue cultures}

IVD tissue samples were dissected and macroscopically separated into AF, NP and EP fragments according to their morphology. From the DD group ( $n=6$ donors), tissue punches with about $6 \mathrm{~mm}$ diameter and $1 \mathrm{~mm}$ height were collected and cultured for $24 \mathrm{~h}$ in serum-free IVD medium: DMEM with low glucose supplemented with $1 \%$ penicillin-streptomycin $(10,000 \mathrm{U} / \mathrm{mL}-10,000 \mu \mathrm{g} / \mathrm{mL}$, $15,140,122$, Gibco $), 0.5 \%$ amphotericin B $(250 \mu \mathrm{g} / \mathrm{mL}$, A2812, Biochrom), $1 \%$ non-essential amino acids (Biochrom) and $1.5 \% 5 \mathrm{M} \mathrm{NaCl} / 0.4 \mathrm{M} \mathrm{KCl}$ solution, at $37^{\circ} \mathrm{C}$, under reduced oxygen supply $\left(6 \% \mathrm{O}_{2}\right.$ and $\left.8.5 \% \mathrm{CO}_{2}\right)$ and saturated humidity. Randomly selected fragments from the three regions were enzymatically digested for $3-5 \mathrm{~h}$ in $0.8 \mathrm{mg} / \mathrm{mL}$ collagenase type II (Sigma-Aldrich) in IVD medium, under agitation, reduced oxygen supply $\left(6 \% \mathrm{O}_{2}\right.$ and $8.5 \% \mathrm{CO}_{2}$ ), $37{ }^{\circ} \mathrm{C}$ and saturated humidity. The suspension was filtered through a $100-\mu \mathrm{m}$ filter (BD Falcon) to remove tissue debris. Cells were collected by centrifugation at $500 \mathrm{~g}$ for $10 \mathrm{~min}$. AF, NP and EP cells were either used directly for flow cytometry analysis or seeded at a density of 3000 cells $/ \mathrm{cm}^{2}$ in IVD medium with $5 \%$ heatinactivated foetal bovine serum (FBS, Gibco). Cells were detached by exposure to $0.050 \%$ trypsin-EDTA (Gibco) for $5 \mathrm{~min}$ at $37^{\circ} \mathrm{C}$ when reaching $70-80 \%$ confluency and expanded up to passages $2-4$.

\section{IVD tissue and cell cultures stimulation}

After $24 \mathrm{~h}$ of culture under serum-free condition in 24-well plates with $1 \mathrm{~mL}$ of medium per well, the tissue punches were stimulated with different culture media $(1 \mathrm{~mL}$ per well). Serum-free IVD medium was supplemented with: (i) 5\% human serum (HS, Quidel) alone or also with (ii) $10 \mathrm{ng} / \mathrm{mL}$ IL-1 $\beta$ (HS + IL-1 $\beta$, R\&D Systems), (iii) $0.5 \mu \mathrm{g} /$ $\mathrm{mL}$ CTSD (HS + CTSD, R\&D Systems) or (iv) $100 \mu \mathrm{g} / \mathrm{mL}$ zymosan (HS + zymosan, Sigma-Aldrich). Tissues kept in serum-free IVD medium were used as control (SF group). After $6 \mathrm{~h}$ of stimulation, the tissue samples were fixed in $4 \%$ formalin and processed for immunohistochemistry.

Cells (5000 cells/well in 96-well plates) were cultured in SF for $24 \mathrm{~h}$. Cells were then cultured for $30 \mathrm{~min}$ with $5 \%$ FBS, $1,2,5$ or $10 \%$ HS and the supplements previously described for tissue cultures. The SF group was kept as control. For each donor, three experimental replicates were analysed. Afterwards, cells were fixed in $4 \%$ formalin for $15 \mathrm{~min}$. 


\section{TCC and CD59 immunohistochemistry}

TCC deposition and CD59 expression were assessed by avidin-biotin complex (Vector Laboratories) immunohistochemistry using NovaRED Peroxidase (HRP) Substrate Kit (Vector laboratories) as previously described [14]. Mouse anti-human C5b-9/TCC (1:250, Quidel) or mouse anti-human CD59 (1:125, Bio-Rad) was used as primary antibodies, followed by incubation with goat anti-mouse $\operatorname{IgG}(\mathrm{H}+\mathrm{L})$, biotin-XX (1:200, Invitrogen) antibody. Isotype controls were stained with mouse IgG antibody (BioLegend). Sections were imaged with light microscopy (Zeiss). Positive cells for TCC formation (TCC + ) and CD59 expression (CD59+) were counted within a defined region and normalized to the total number of cells within the same region.

\section{Soluble TCC ELISA}

Levels of non-lytic S-protein-bound TCC, also referred to as soluble TCC [16], in tissue and cell culture supernatants were analysed using a human ELISA kit (BD Biosciences), following the manufacturer's instructions.

\section{Flow cytometry analysis of cellular complement regulators}

After cell isolation from AF, NP and EP, red blood cells were lysed with $10 \mathrm{mM}$ Tris/150 $\mathrm{mM} \mathrm{NH}_{4} \mathrm{Cl}$, $\mathrm{pH} 7.4$, for $8 \mathrm{~min}$ at $37^{\circ} \mathrm{C}$. Expanded cells (passages 2-4) were trypsinized and incubated for $1 \mathrm{~h}$ in IVD medium. Cell surface staining was performed by incubation with the antibodies from Table 1, for $30 \mathrm{~min}$ on ice. Samples were analysed by flow cytometry (FACSCalibur, BD) and data evaluated with FlowJo software version 10 (Ashland).

\section{TCC cell-based ELISA}

For quantification of TCC deposition in in vitro cell cultures, a cell-based ELISA was used [17]. Briefly, after a blocking step with 5\% bovine serum albumin (SigmaAldrich) in DPBS at $37{ }^{\circ} \mathrm{C}$ for $1 \mathrm{~h}$, cells were incubated for $2 \mathrm{~h}$ at $37{ }^{\circ} \mathrm{C}$ with anti-C5b-9/TCC antibody $(1: 4000$ dilution, Abcam). Anti-rabbit $\operatorname{IgG}$ peroxidase $(1: 10,000$ dilution, Sigma-Aldrich) was used as secondary antibody. After $1 \mathrm{~h}$ of incubation at room temperature with the secondary antibody, cells were incubated with $3,3^{\prime}, 5$, 5 '-tetramethylbenzidine (TMB) substrate (Sigma-Aldrich) for $15 \mathrm{~min}$ at room temperature. Before the addition of stop solution (R\&D Systems), $50 \mu \mathrm{L}$ of the TMB solution was transferred to a new plate, to prevent cell lysis by the sulfuric acid. Absorbance values were measured at $450 \mathrm{~nm}$. The cells were washed twice with PBS and imaged with light microscopy (Zeiss). DNA concentration was determined using the Quant-iT PicoGreen doublestandard DNA kit (Invitrogen), following the manufacturer's instructions.

\section{Statistical analysis}

Results are presented in box-and-whisker plots as median \pm interquartile range, showing all points. Normality was assessed by Shapiro-Wilk normality test, after which statistical analysis was performed with parametric one-way ANOVA or nonparametric Kruskal-Wallis test, followed by Dunn's multiple comparison test, using GraphPad Prism 9 (GraphPad Software, Inc., USA). Statistical significance was considered for $P<0.05$.

Table 1 Antibodies used in flow cytometry analysis

\begin{tabular}{|c|c|c|c|c|c|}
\hline Antibody & Function & Fluorochrome & Dilution & Clone & Catalog no., manufacturer \\
\hline \multicolumn{6}{|l|}{ Primary antibody } \\
\hline $\mathrm{IgG}_{1}$ mouse anti-human CD46 & $\begin{array}{l}\text { Cell surface transmembrane protein that } \\
\text { binds and inactivates } \mathrm{C} 3 \mathrm{~b} \text { and } \mathrm{C} 4 \mathrm{~b} \text { comple- } \\
\text { ment fragments }\end{array}$ & FITC & $2: 50$ & MEM-258 & 21,270,463, Immunotools \\
\hline $\mathrm{IgG}_{2 \mathrm{a}}$ mouse anti-human CD55 & $\begin{array}{l}\text { Protects autologous cells from classical and } \\
\text { alternative pathway of complement cascade }\end{array}$ & APC & $2: 50$ & HI55a & 21,810,556, Immunotools \\
\hline $\mathrm{IgG}_{1}$ mouse anti-human CD59 & $\begin{array}{l}\text { Protects autologous cells from terminal } \\
\text { effector mechanism of the complement } \\
\text { cascade }\end{array}$ & APC & $2: 50$ & MEM-43 & 21,270,596, Immunotools \\
\hline \multicolumn{6}{|l|}{ Isotype control } \\
\hline Mouse $\mathrm{IgG}_{1}$ & & FITC & $2: 50$ & PPV-06 & 21,275,513, Immunotools \\
\hline Mouse $\operatorname{IgG}_{2 \mathrm{a}}$ & & APC & $2: 50$ & PPV-04 & 21,275,526, Immunotools \\
\hline Mouse $\mathrm{IgG}_{1}$ & & APC & $2: 50$ & PPV-06 & 21,275,516, Immunotools \\
\hline
\end{tabular}




\section{Results}

\section{TCC formation and CD59 expression in disc tissue cultures}

Tissue cultures were performed to investigate whether the different stimulation factors influence IVD cells kept in their 3D microenvironment. A significantly higher percentage of TCC + cells was found in the presence of complementcompetent HS in AF (2.4-fold, $P<0.01)$, NP (1.7-fold, $P$ $<0.05)$ and EP (4.9-fold, $P<0.05)$ cells compared to SF, with the highest increase observed for EP (Fig. 1a; representative staining images in Supplemental Fig. S1). Addition of IL-1 $\beta$ resulted in lower TCC formation than in the HS group, which was significant for AF and EP $(P<0.05)$. CTSD stimulation contributed to an increase in TCC deposition
$(P<0.05)$ in NP, whereas zymosan increased TCC in EP $(P<0.05)$. No soluble TCC was detected in the SF groups (Fig. 1b). In AF cultures, less soluble TCC was detected in supernatants from HS + IL- $1 \beta$ and HS + CTSD groups, in comparison with HS alone $(P<0.05)$. In NP tissues, higher soluble TCC was generated after zymosan stimulation $(P<0.01)$. No differences were found in EP. CD59 expression was assessed by immunohistochemistry (Fig. 1c; representative staining images in Supplemental Fig. S2), and it was rather low (percentage of CD59 + cells $<40 \%$ ) in all conditions tested. Nevertheless, although no differences were found in AF, a significantly higher percentage of CD59 + cells was found after stimulation of NP tissues by HS + CTSD versus HS alone (2.6-fold, $P<0.05)$. In EP, significantly higher percentage of CD59+cells was detected in the HS group in contrast to all other groups $(P<0.01)$.
Fig. 1 Analysis of TCC formation on IVD tissue punches from annulus fibrosus (AF), nucleus pulposus (NP) and endplate (EP) tissue punches after $6 \mathrm{~h}$ of stimulation with serumfree medium (SF), medium containing 5\% human serum (HS) alone or supplemented with IL-1 $\beta$ (10 ng/mL, HS + IL-1 $\beta)$, CTSD (CTSD, $0.5 \mu \mathrm{g} / \mathrm{mL}$, HS + CTSD) or zymosan (100 $\mu \mathrm{g} / \mathrm{mL}$, HS + zymosan). Tissues were collected from patients diagnosed with disc degeneration. Percentage of $\mathrm{TCC}+$ cells in AF, NP and EP tissue punches (a). Soluble TCC $(\mu \mathrm{g} / \mathrm{mL})$ detected in the culture supernatants (b). Percentage of CD59+ cells in AF, NP and EP tissue punches (c). Results are presented as box-and-whisker plots as median \pm interquartile range ( $n=6$ donors per group). $* P<0.05 ; * * P<0.01$, repeated measures one-way ANOVA, with the Greenhouse-Geisser correction
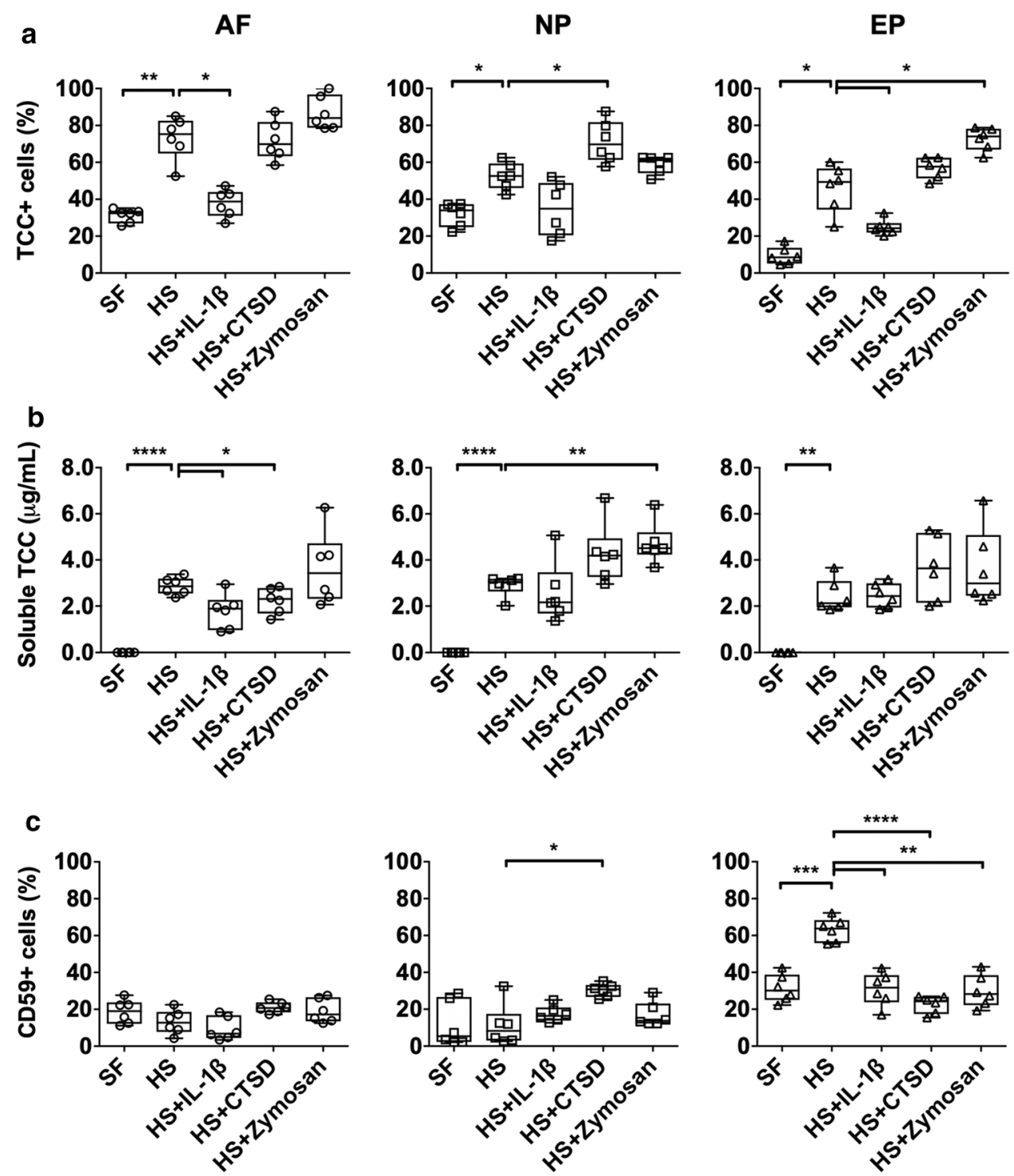
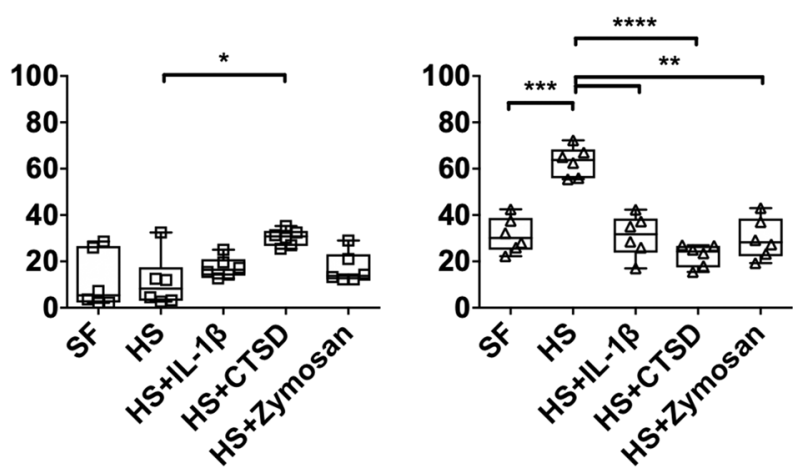
a

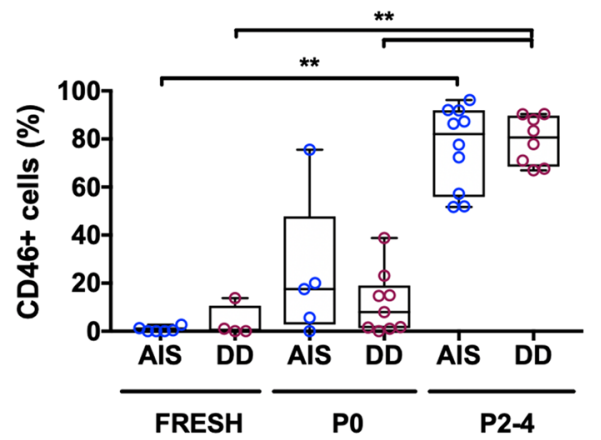

b
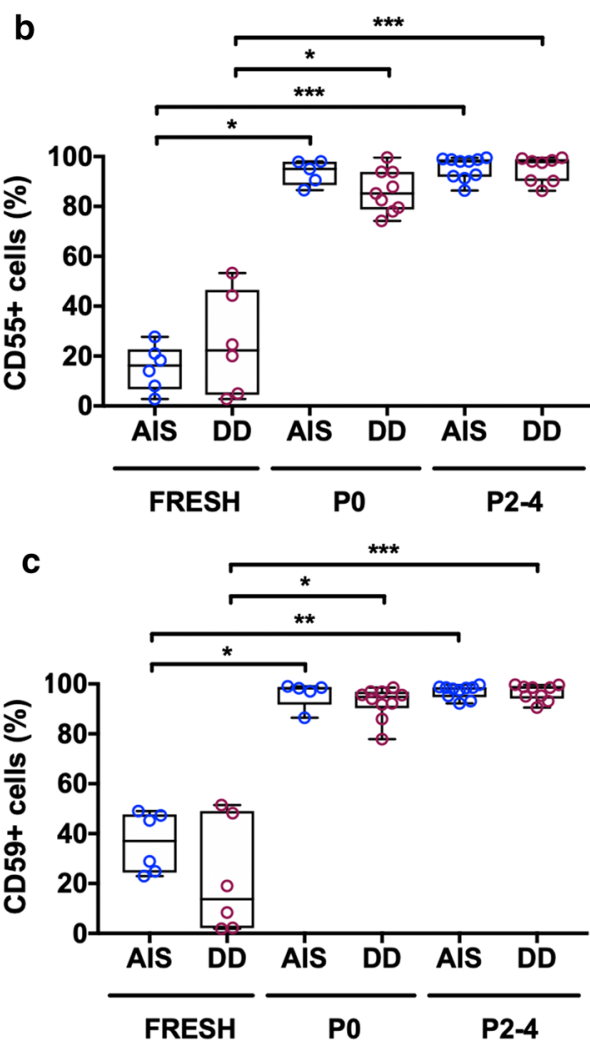
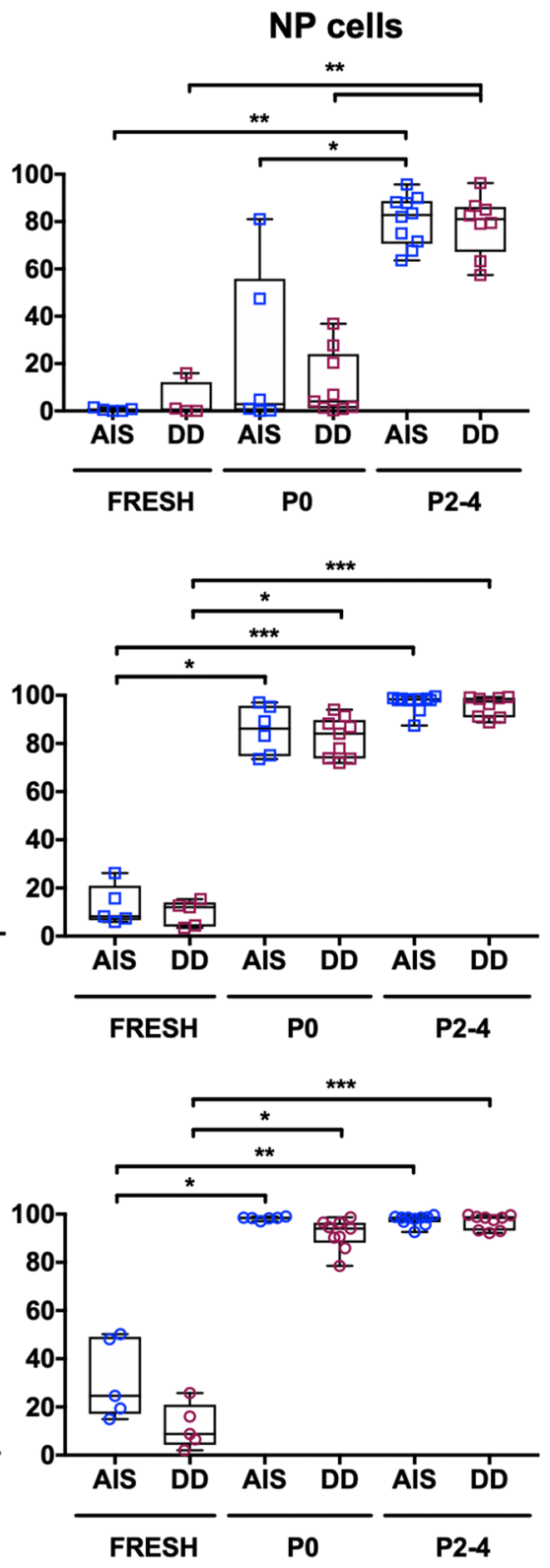

EP cells
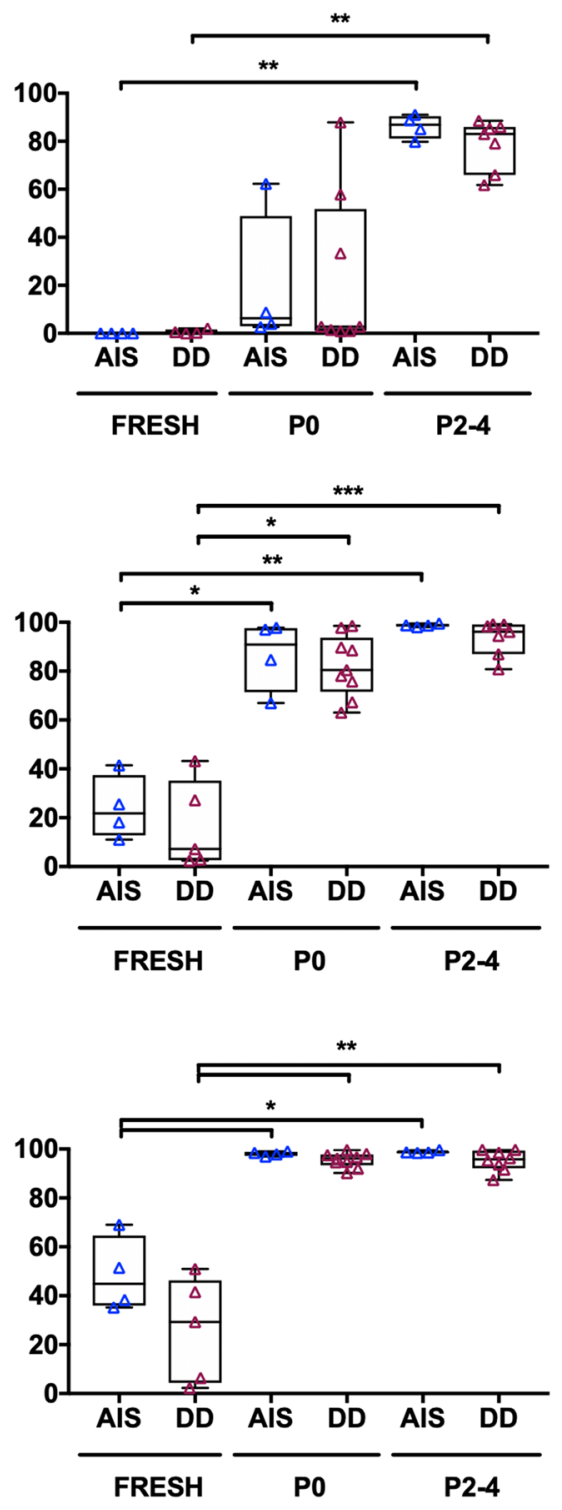

Fig. 2 Cell surface detection of membrane-bound complement regulators in annulus fibrosus (AF), nucleus pulposus (NP) and endplate (EP) freshly isolated cells (FRESH), at passage 0 (P0) and after cell expansion (P2-4), from adolescent idiopathic scoliosis (AIS) and disc degeneration (DD) patient groups. Percentage of CD46+(a), $\mathrm{CD} 55+(\mathbf{b})$ and CD59+(c) cells. Results are presented in box-andwhisker plots as median \pm interquartile range $(n=4-10$ donors per group). $* P<0.05 ; * * P<0.01 ; * * * P<0.001$, Kruskal-Wallis test

\section{Flow cytometry analysis of cellular complement regulators}

$\mathrm{AF}, \mathrm{NP}$ and EP cells from AIS and DD patients were analysed by flow cytometry for membrane-bound CRegs CD46, CD55 and CD59 (Fig. 2). Cells from AIS and DD patients were analysed at different timepoints: directly after isolation from the disc tissue (FRESH), after the first trypsinization (P0) and after expansion, in passages 2-4 (P2-4). Due to the limited number of cells, it was not possible to track the cells from the same patient along time. Overall, at the same timepoint of analysis, no differences were observed between cells from AIS and DD patients regarding the expression of the different markers. Very low CD46 expression was detected in FRESH cells (CD46 + cells $<15 \%$, Fig. 2a), whereas at P0, higher expression of CD46 was just detected in some donors. In P2-4, a significant increase in the percentage of AF, $\mathrm{NP}$ and EP cells expressing CD46 was found, particularly when compared to FRESH groups $(P<0.01)$. The 
expression of CD55 (Fig. 2b) and CD59 (Fig. 2c) followed a similar pattern. For all cell types, there was a significant increase in the expression of CD55 and CD59 in P0 $(P<0.05)$ and P2-4 $(P<0.01)$, compared to FRESH samples, which ranged between 60 and $100 \%$ positivity. Interestingly, some DD donors presented lower percentage of CD59 + cells than AIS, but without overall statistical significance. Gene expression of CD46, CD55 and CD59 by AF, NP and EP cells in passages 2-4 was also analysed (Supplemental Figure S3). No differences were observed between AIS and DD groups, except for CD55 expression by NP cells, for which a higher expression was observed in DD compared to AIS (threefold, $P<0.05$ ). When comparing the expression of each marker by cells from different regions, higher $C D 46$ expression was found in NP cells versus AF cells from AIS patients (threefold, $P<0.01$ ) and in NP and EP cells in comparison with AF cells from DD patients (about twofold to threefold, $P<0.05$ ). Moreover, higher $C D 55$ expression was observed in EP versus AF cells from DD patients (threefold, $P<0.05$ ).
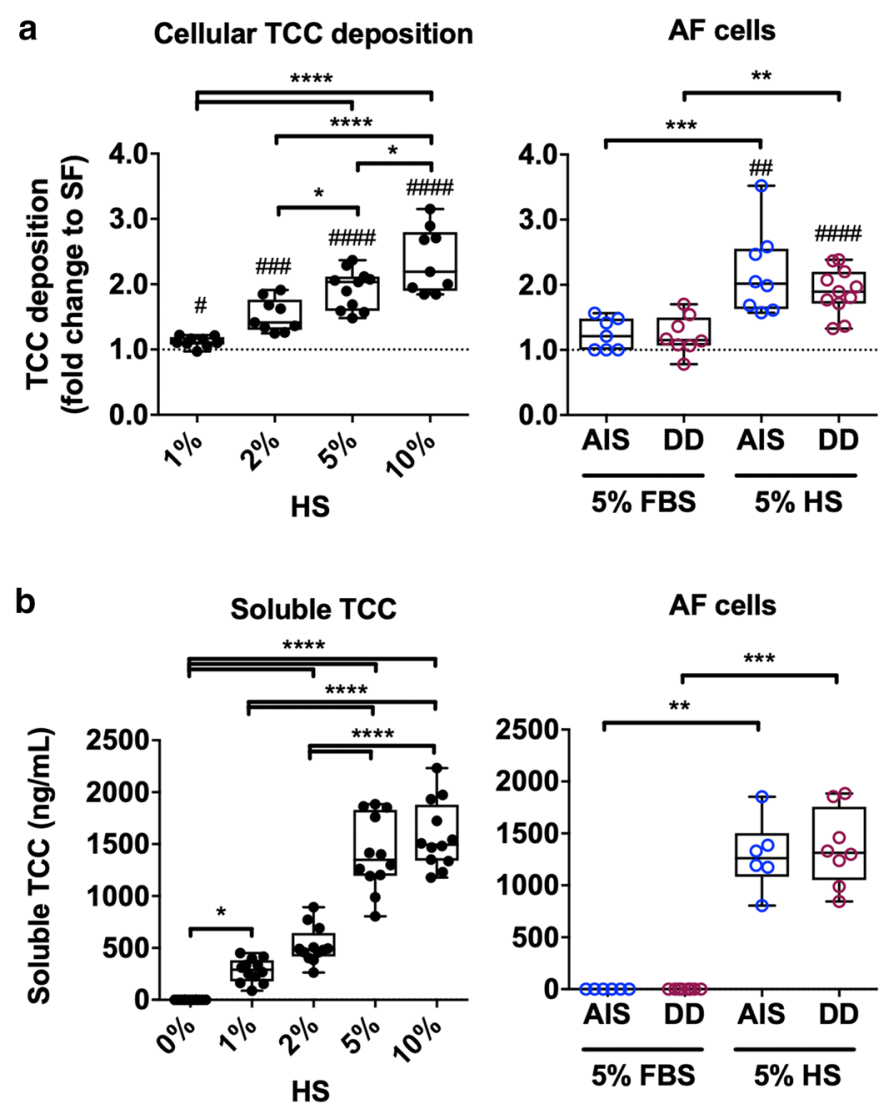

Fig. 3 Analysis of TCC formation on isolated annulus fibrosus (AF), nucleus pulposus (NP) and endplate (EP) cells after culture with different concentrations of human serum (HS) for $30 \mathrm{~min}$. Cellular TCC deposition after cell culture with medium supplemented with 1,2 , 5 and $10 \%$ HS, respectively, and of cells from adolescent idiopathic scoliosis (AIS) and disc degeneration (DD) patients cultured with 5\%

\section{TCC formation in IVD cell cultures}

Cells in P2-4 were stimulated with different concentrations of HS and compared with standard IVD cell culture medium containing 5\% heat-inactivated FBS (Fig. 3). Both cellular TCC deposition (Fig. 3a) and soluble TCC formation (Fig. 3b) increased with increasing complement-competent HS in a concentration-dependent manner $(P<0.05)$. In cell cultures with $5 \%$ heat-inactivated FBS, TCC formation was not detected in the supernatants similar to SF. Again, higher cellular and soluble TCC formation was found in cells stimulated with 5\% HS $(P<0.05)$, but with no differences between AIS and DD groups.

Since AF, NP and EP cells isolated from AIS and DD patients behaved similarly after isolation and expansion (as shown in Figs. 2, 3 and supplemental Figure S3), Fig. 4 shows data from both AIS and DD patient-derived cells. In cell culture experiments, stimulation with IL- $1 \beta$, CTSD or zymosan did not alter TCC deposition in comparison with HS alone (Fig. 4a); however, significantly higher
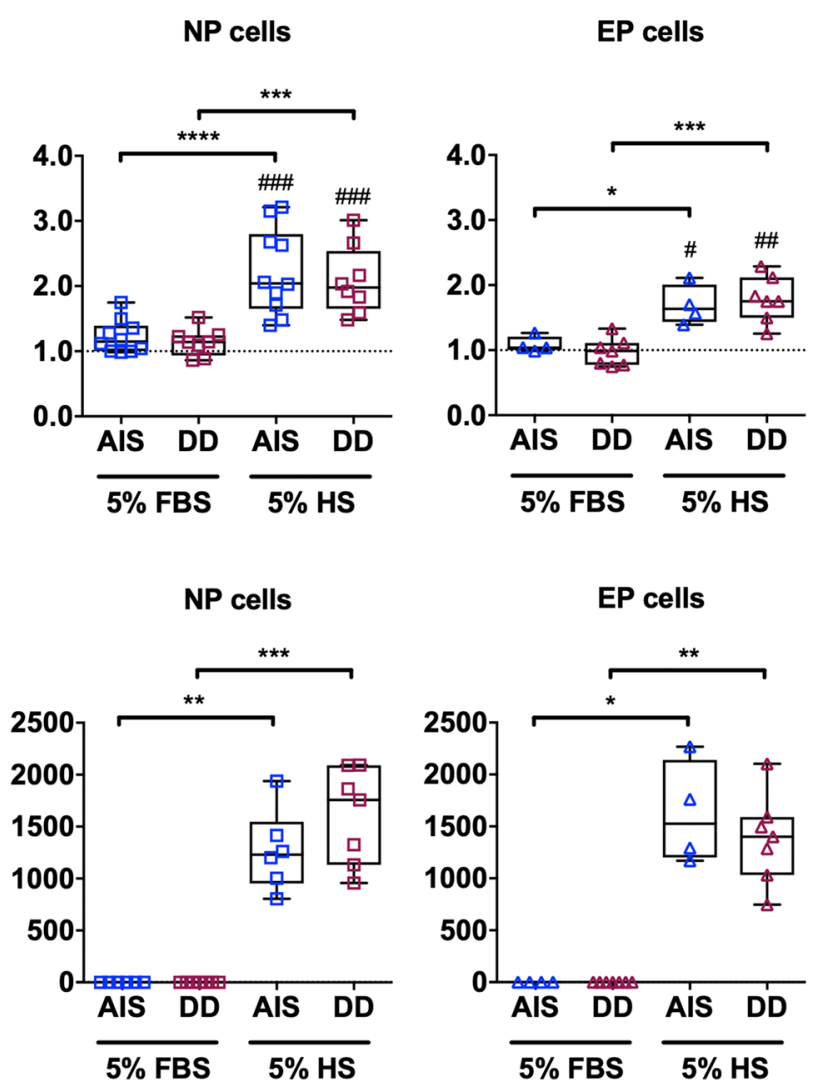

heat-inactivated foetal bovine serum $(5 \% \mathrm{FBS})$ or $5 \%$ human serum (5\% HS). Data were normalized to serum-free medium (SF) group (a). Soluble TCC $(\mu \mathrm{g} / \mathrm{mL})$ detected in the culture supernatants (b). Results are presented in box-and-whisker plots as median \pm interquartile range $\left(n=4-12\right.$ donors per group). ${ }^{*} P<0.05 ; * * P<0.01$; $* * * P$ $<0.001 ; * * * * P<0.0001$, ordinary one-way ANOVA 
Fig. 4 Analysis of TCC formation on isolated annulus fibrosus (AF), nucleus pulposus (NP) and endplate (EP) cells after 30 min of stimulation with medium containing $5 \%$ human serum (HS) alone or supplemented with IL-1 $\beta(10 \mathrm{ng} / \mathrm{mL}$, HS + IL-1 $\beta$ ), CTSD (CTSD, $0.5 \mu \mathrm{g} / \mathrm{mL}, \mathrm{HS}+\mathrm{CTSD})$ or zymosan $(100 \mu \mathrm{g} / \mathrm{mL}$, HS + zymosan). Serum-free medium cultures (SF) were kept as control. Cellular TCC deposition normalized to $\mathrm{SF}$ group (a). Soluble TCC $(\mu \mathrm{g} / \mathrm{mL})$ detected in the culture supernatants (b). Results are presented as box-and-whisker plots as median \pm interquartile range ( $n=6-10$ donors per group). ${ }^{\#} P<0.05 ;{ }^{\# \#}<0.01 ;{ }^{\# \# \#} P$ $<0.001$ (significant differences with respect to SF group); $* P$ $<0.05$; ** $P<0.01$ (significant differences with respect to HS group), Kruskal-Wallis test

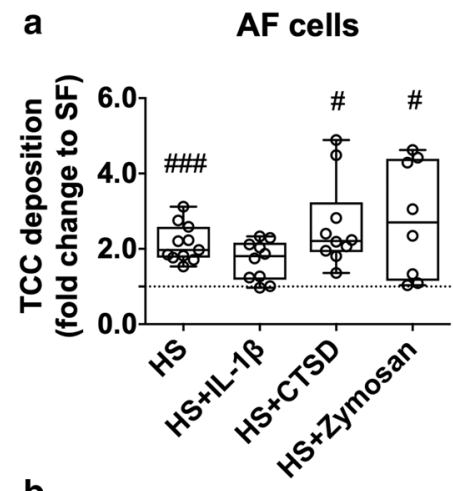

b

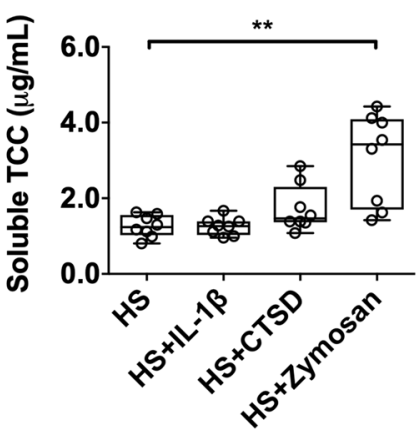

EP cells

NP cells
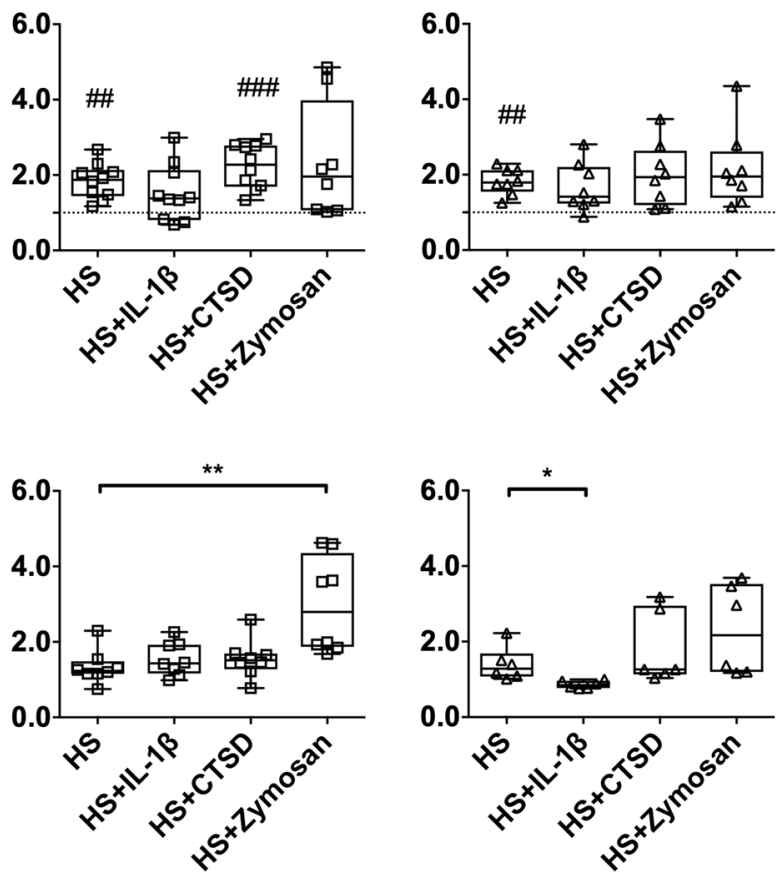

deposition was observed for HS in all cell types $(P<0.01)$, for HS + CTSD in AF $(P<0.05)$ and NP $(P<0.001)$ and for $\mathrm{HS}+$ zymosan in AF $(P<0.05)$ compared to SF. More soluble TCC was detected in supernatants of AF and NP cells stimulated with HS + zymosan versus HS alone $(P<0.01)$, whereas less TCC was found in supernatants of EP cells stimulated with HS + IL-1 $\beta(P<0.05$, Fig. 4b).

\section{Discussion}

To investigate whether TCC formation can be activated in vitro and to identify possible modulating factors known to be involved in disc degeneration, such as IL-1 $\beta$ and CTSD, human IVD tissue and isolated cell cultures were conducted. IL-1 $\beta$ is a key pro-inflammatory factor involved in DD [18]. CTSD is a matrix-degrading enzyme previously identified in human degenerated disc tissues [7] that increases during catabolic activity, such as in DD [19, 20]. In the present study, an additional group stimulated with zymosan was included as positive control. This polysaccharide derived from yeast cell walls has been shown to robustly activate the complement system through the alternative pathway [21] and to cause inflammation in different tissues [22-24].

Overall, the results clearly indicate that human IVD cells are not able to completely protect themselves against complement attack in culture. Exposure to HS alone increased TCC deposition on isolated IVD cells (AF, NP and EP) in a dose-dependent manner. HS contains all the necessary components (C5b-C9) for TCC formation [25]. Its TCCforming capacity was proven in an erythrocyte lysis test (Supplemental Figure S3). Despite enhanced expression levels of CRegs on isolated IVD cells, TCC deposition was significantly increased after stimulation with 5\% HS. Therefore, this concentration was considered sufficient and selected for further experiments. In a previous study, fixed human IVD tissues presented higher TCC deposition in several patients diagnosed with DD compared to AIS, which was significantly higher in NP tissue, most likely due to differences in immune cell infiltration [14].

Modulation of TCC was not similar between cell and organ cultures. In monolayer cultures, no significant effects of the different medium supplements on TCC formation by AF, NP or EP cells were detected after 30 min of incubation. A longer stimulation period of $6 \mathrm{~h}$ was investigated in the organ cultures in order to ensure exposure of disc cells to complement factors present in HS in their native environment. Moreover, passage-dependent changes in the expression profiles of CRegs were observed, which might alter the response of IVD cells in monolayer compared to their three-dimensional tissue environment. Interestingly, TCC deposition on AF and EP tissues was significantly decreased (with the co-stimulation) in the presence of IL-1 $\beta$. It is a key molecule produced by IVD cells during degeneration [18] and is responsible to promote the activation of immune cells including macrophages [26, 27] and the expression of matrix-degrading enzymes, such as MMP-3 [28]. Moreover, IL- $1 \beta$ is an early mediator of the inflammatory response 
involved in a variety of cellular activities, including cell proliferation, differentiation and apoptosis [29]. It has also been shown to induce production of the central complement component $\mathrm{C} 3$ in vitro by a human intestinal epithelial cell line [30].

Concerning sources of IL- $1 \beta$, the activation of the complement system, and subsequent generation of anaphylatoxins $\mathrm{C} 3 \mathrm{a}$ and $\mathrm{C} 5 \mathrm{a}$, has been shown to promote its production [31, 32]. For instance, $\mathrm{C} 3 \mathrm{a}$ is known to increase IL-1 $\beta$ secretion in human tenocytes [33] and monocytes and regulates the inflammasome activation [34]. Likewise, $\mathrm{C} 5 \mathrm{a}$ is able to induce the synthesis of IL- $1 \beta$ by monocytes and macrophages [35]. However, whether the production of pro-inflammatory molecules contributes to the TCC formation has not yet been investigated. Regulation can occur at different stages of the complement activation cascade by membrane-bound CRegs such as CD46, CD55 or CD59 or fluid-phase proteins such as vitronectin, clusterin or factorI. IL-1 $\beta$ and TNF- $\alpha$ have been described to upregulate the expression of CD46, CD55 and CD59 by chondrocytes

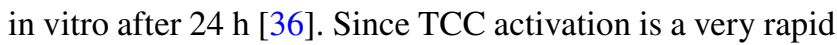
process, we selected short stimulation times of $30 \mathrm{~min}$ for cell culture and $6 \mathrm{~h}$ for tissue culture studies. Therefore, effects of IL- $1 \beta$ involving induction of regulatory protein expression probably cannot explain the observed inhibitory influence on TCC deposition in the experimental setting. Interestingly, IL- $1 \beta$ is known to bind to both, $\mathrm{C} 3 \mathrm{~b}$ and alpha2-macroglobulin [37]; thus, complement modulation via a direct interaction could be more likely relevant [38]. The protein complex formation of IL- $1 \beta, \mathrm{C} 3 \mathrm{~b}$ and alpha2macroglobulin might impair further processing of $\mathrm{C} 3 \mathrm{~b}$ and/ or activate the protease inhibitor activity of alpha2-macroglobulin. However, further mechanistic studies will be needed to understand the complex interplay between proinflammatory molecules - especially IL- $1 \beta$ - and the complement activation cascade.

In NP tissue, TCC deposition increased in the presence of CTSD. Besides other proteases, CTSD has been described as a potential complement activator by direct cleavage of $\mathrm{C} 5$ and subsequent generation of functional C5a [39] which is accompanied by generation of $\mathrm{C} 5 \mathrm{~b}$ as initial component of TCC formation. Moreover, this endo-protease contributes to the cleavage of cartilaginous matrix components, such as aggrecan [40]. CTSD has been previously identified in degenerated IVDs. It was also colocalized with cells from the cleft between the cartilaginous EP and vertebral body, indicating its association with endplate separation and $\mathrm{AF}$ disorganization [7]. Furthermore, the presence of the tissue renin-angiotensin system (tRAS) components, including CTSD, has been recently associated with inflammation and subsequent degeneration of IVD tissue [19, 20]. Since CTSD can replace renin as a renin-like enzyme to generate angiotensin I and angiotensin II, which interacts with the angiotensin II receptors to induce pro-inflammatory signals [19], CTSD-mediated induction of tRAS might be plausible. The results described in the present manuscript further indicate that CTSD may also be involved in the activation of the terminal part of the complement cascade.

Of note, the CReg CD59 expression did not follow a specific pattern compared to TCC formation. However, the duration of HS exposition was very short. In an injury model of cartilage explants, an increase in gene expression of CD59 and clusterin - another TCC inhibitor-was measured after 4 days of HS stimulation [41]. Interestingly, CD55 and CD59 were shown to be expressed in disc cells (even freshly isolated) and rapidly increased under culture with 5\% heatinactivated FBS. At protein level, CD46 did not seem to be present in freshly isolated cells and increased slower than the other complement regulatory factors CD55 and CD59. These results indicate for the first time that IVD cells differentially express CRegs supporting some functional relevance of the complement system in IVD tissues.

Based on findings for osteoarthritis [42], inhibition of TCC formation could be a promising therapeutic strategy against DD. This work presents substantial new information on the cell biological connection between IL-1 $\beta$, CTSD and TCC formation in IVD tissue, which might open new perspectives to identify more effective DD therapeutic targets. We propose CTSD as an interesting candidate. Its inhibition might not only directly protect from degradation of extracellular matrix components but also attenuate inflammation and tissue degeneration induced by tRAS, as well as from complement activation associated processes. With respect to TCC involvement in disc degeneration, further studies are important to better understand the complexity of underlying mechanisms of its regulation and potential contribution to inflammation and cell death.

\section{Conclusion}

Our findings indicate that TCC deposition can spontaneously occur in vitro in the presence of HS in a concentrationdependent manner. This confirms that human disc cells are not completely protected against TCC formation, although they express a certain capacity of CRegs. Our results also show that CTSD, an aspartic acid protease which plays a role in tRAS and complement activation, increases TCC deposition in NP tissue. In contrast, IL- $1 \beta$ seems to inhibit complement activation in AF and EP to a certain extent. Elucidation of the complex mechanisms of complement modulation in DD and its interplay with other pathogenetic processes holds great promise for identification of novel therapeutic targets.

Supplementary Information The online version contains supplementary material available at https://doi.org/10.1007/s00586-021-06901-5. 
Acknowledgements The authors of the present study wish to acknowledge Dr. Helga Joos, Dr. Taryn Saggese and Mrs. Iris Baum for their technical support.

Funding Open Access funding enabled and organized by Projekt DEAL. This study was supported by the German Research Foundation (NE 549/6-1, BR 919/12-1), German Academic Exchange Service, Conselho de Reitores das Universidades Portuguesas and the Alexander von Humboldt Foundation. Jana Riegger is supported by the European Social Fund and by the Ministry of Science, Research and Arts Baden-Württemberg.

\section{Declaration}

Conflict of interest The authors declare that they have no conflict of interest.

Ethical approval Informed consent for sample collection was obtained from all individual patients, and the study was approved by the local ethical committees (208/15 Ulm University, Germany; S-051/2016 Heidelberg University, Germany).

Open Access This article is licensed under a Creative Commons Attribution 4.0 International License, which permits use, sharing, adaptation, distribution and reproduction in any medium or format, as long as you give appropriate credit to the original author(s) and the source, provide a link to the Creative Commons licence, and indicate if changes were made. The images or other third party material in this article are included in the article's Creative Commons licence, unless indicated otherwise in a credit line to the material. If material is not included in the article's Creative Commons licence and your intended use is not permitted by statutory regulation or exceeds the permitted use, you will need to obtain permission directly from the copyright holder. To view a copy of this licence, visit http://creativecommons.org/licenses/by/4.0/.

\section{References}

1. Cheung KMC, Karppinen J, Chan D, Ho DWH, Song YQ, Sham P et al (2009) Prevalence and pattern of lumbar magnetic resonance imaging changes in a population study of one thousand forty-three individuals. Spine Phila Pa 1976 34:934-940. https://doi.org/10. 1097/BRS.0b013e3181a01b3f

2. Duance VC, Crean JK, Sims TJ, Avery N, Smith S, Menage J et al (1998) Changes in collagen cross-linking in degenerative disc disease and scoliosis. Spine Phila Pa 1976 23:2545-2551. https:// doi.org/10.1097/00007632-199812010-00009

3. Pokharna HK, Phillips FM (1998) Collagen crosslinks in human lumbar intervertebral disc aging. Spine Phila Pa 1976 23:1645168. https://doi.org/10.1097/00007632-199808010-00005

4. Capossela S, Schläfli P, Bertolo A, Janner T, Stadler BM, Pötzel $T$ et al (2014) Degenerated human intervertebral discs contain autoantibodies against extracellular matrix proteins. Eur Cell Mater 27:251-263. https://doi.org/10.22203/ecm.v027a18

5. Adams MA, Roughley PJ (2006) What is intervertebral disc degeneration, and what causes it? Spine Phila Pa 1976 31:21512161. https://doi.org/10.1097/01.brs.0000231761.73859.2c

6. Vergroesen PP, Kingma I, Emanuel KS, Hoogendoorn RJW, Welting TJ, van Royen BJ et al (2015) Mechanics and biology in intervertebral disc degeneration: a vicious circle. Osteoarthr Cartil 23:1057-1070. https://doi.org/10.1016/j.joca.2015.03.028
7. Ariga K, Yonenobu K, Nakase T, Kaneko M, Okuda S, Uchiyama $\mathrm{Y}$ et al (2001) Localization of cathepsins D, K, and L in degenerated human intervertebral discs. Spine Phila Pa 1976 26:26662672. https://doi.org/10.1097/00007632-200112150-00007

8. Molinos M, Almeida CR, Caldeira J, Cunha C, Gonçalves RM, Barbosa MA (2015) Inflammation in intervertebral disc degeneration and regeneration. J R Soc Interface 12:20141191. https://doi. org/10.1098/rsif.2014.1191

9. Risbud MV, Shapiro IM (2014) Role of cytokines in intervertebral disc degeneration: pain and disc content. Nat Rev Rheumatol 10:44-56. https://doi.org/10.1038/nrrheum.2013.160

10. Teixeira GQ, Gonçalves RM, Barobosa MA (2018) Immunomodulation in degenerated intervertebral disc. In: Gonçalves RM, Barbosa MA (eds) Gene and cell delivery for intervertebral disc degeneration, 1 st edn. CRC Press, Boca Raton, $\mathrm{p} 48$

11. Ricklin D, Lambris JD (2013) Complement in immune and inflammatory disorders: pathophysiological mechanisms. J Immunol 190:3831-3838. https://doi.org/10.4049/jimmunol. 1203487

12. Morgan BP (2016) The membrane attack complex as an inflammatory trigger. Immunobiology 221:747-751. https://doi.org/10. 1016/j.imbio.2015.04.006

13. Grönblad M, Habtemariam A, Virri J, Seitsalo S, Vanharanta H, Guyer RD (2003) Complement membrane attack complexes in pathologic disc tissues. Spine Phila Pa 1976 28:114-118. https:// doi.org/10.1097/00007632-200301150-00004

14. Teixeira GQ, Yong Z, Goncalves RM, Kuhn A, Riegger J, Brisby $\mathrm{H}$ et al (2020) Terminal complement complex formation is associated with intervertebral disc degeneration. Eur Spine J 30:217226. https://doi.org/10.1007/s00586-020-06592-4

15. Ruiz-Argüelles A, Llorente L (2007) The role of complement regulatory proteins (CD55 and CD59) in the pathogenesis of autoimmune hemocytopenias. Autoimmun Rev 6:155-161. https://doi. org/10.1016/j.autrev.2006.09.008

16. Johnson E, Berge V, Høgåsen K (1994) Formation of the terminal complement complex on agarose beads: further evidence that vitronectin (complement S-protein) inhibits C9 polymerization. Scand J Immunol 39:281-285. https://doi.org/10.1111/j.13653083.1994.tb03372.x

17. Jeon H, Lee JS, Yoo S, Lee MS (2014) Quantification of complement system activation by measuring C $5 b-9$ cell surface deposition using a cell-ELISA technique. J Immunol Methods 415:57-62. https://doi.org/10.1016/j.jim.2014.09.002

18. Johnson ZI, Schoepflin ZR, Choi H, Shapiro IM, Risbud MV (2015) Disc in flames: roles of TNF- $\alpha$ and IL-1 $\beta$ in intervertebral disc degeneration. Eur Cells Mater 30:104-117. https://doi.org/ 10.22203/ecm.v030a08

19. Morimoto R, Akeda K, Iida R, Nishimura A, Tsujii M, Obata S et al (2013) Tissue renin-angiotensin system in the intervertebral disc. Spine Phila Pa 1976 38:E129-E136. https://doi.org/10.1097/ BRS.0b013e31827b8c89

20. Li Z, Wystrach L, Bernstein A, Grad S, Alini M, Richards RG et al (2020) The tissue-renin-angiotensin-system of the human intervertebral disc. Eur Cell Mater 40:115-132. https://doi.org/ 10.22203/eCM.v040a07

21. Smith MC, Pensky J, Naff GB (1982) Inhibition of zymosaninduced alternative complement pathway activation by concanavalin A. Infect Immun 38:1279-1284. https://doi.org/10.1128/ IAI.38.3.1279-1284.1982

22. Rahat MA, Brod V, Amit-Cohen BC, Henig O, Younis S, Bitterman $\mathrm{H}$ (2016) Oxygen mitigates the inflammatory response in a model of hemorrhage and zymosan-induced inflammation. Shock 45:198-208. https://doi.org/10.1097/SHK.0000000000000492

23. Mazur-Bialy AI, Pocheć E (2016) HMGB1 inhibition during zymosan-induced inflammation: the potential therapeutic action 
of riboflavin. Arch Immunol Ther Exp Warsz 64:171-176. https:// doi.org/10.1007/s00005-015-0366-6

24. Lima JBM, Veloso CC, Vilela FC, Giusti-Paiva A (2017) Prostaglandins mediate zymosan-induced sickness behavior in mice. J Physiol Sci 67:673-679. https://doi.org/10.1007/ s12576-016-0494-8

25. Ivanov PA, Faktor MI, Karpova NS, Cheremnykh EG, Brusov OS (2016) Complement-mediated death of ciliate tetrahymena pyriformis caused by human blood serum. Bull Exp Biol Med 160:775-778. https://doi.org/10.1007/s10517-016-3307-4

26. Yoshida M, Nakamura T, Sei A, Kikuchi T, Takagi K, Matsukawa A (2005) Intervertebral disc cells produce tumor necrosis factor alpha, interleukin-1beta, and monocyte chemoattractant protein-1 immediately after herniation: an experimental study using a new hernia model. Spine Phila Pa 1976 30:55-61. https://doi.org/10. 1097/01.brs.0000149194.17891.bf

27. Zhang Q, Wang H, Mao C, Sun M, Dominah G, Chen L et al (2018) Fatty acid oxidation contributes to IL- $1 \beta$ secretion in M2 macrophages and promotes macrophage-mediated tumor cell migration. Mol Immunol 94:27-35. https://doi.org/10.1016/j. molimm.2017.12.011

28. Nagase H, Visse R, Murphy G (2006) Structure and function of matrix metalloproteinases and TIMPs. Cardiovasc Res 69:562573. https://doi.org/10.1016/j.cardiores.2005.12.002

29. Lin LR, Liu W, Zhu XZ, Chen YY, Gao ZX, Gao K et al (2018) Treponema pallidum promotes macrophage polarization and activates the NLRP3 inflammasome pathway to induce interleukin- $1 \beta$ production. BMC Immunol 19:28. https://doi.org/10.1186/ s12865-018-0265-9

30. Moon MR, Parikh AA, Pritts TA, Kane C, Fischer JE, Salzman AL et al (2000) Interleukin-1 beta induces complement component C3 and IL-6 production at the basolateral and apical membranes in a human intestinal epithelial cell line. Shock 13:374-378. https://doi.org/10.1097/00024382-200005000-00005

31. Yang S, Li L, Zhu L, Zhang C, Li Z, Guo Y et al (2019) Aucubin inhibits IL- $1 \mathrm{~b} \beta$ - or TNF- $\alpha$-induced extracellular matrix degradation in nucleus pulposus cell through blocking the miR-140-5p/ CREB1 axis. J Cell Physiol 234:13639-13648. https://doi.org/10. $1002 /$ jcp. 28044

32. Batra R, Suh MK, Carson JS, Dale MA, Meisinger TM, Fitzgerald $M$ et al (2018) IL-1 $\beta$ (interleukin-1 $\beta$ ) and TNF- $\alpha$ (tumor necrosis factor- $\alpha$ ) impact abdominal aortic aneurysm formation by differential effects on macrophage polarization. Arterioscler Thromb Vasc Biol 38:457-463. https://doi.org/10.1161/ATVBAHA.117. 310333

33. Busch C, Girke G, Kohl B, Stoll C, Lemke M, Krasnici S et al (2013) Complement gene expression is regulated by pro-inflammatory cytokines and the anaphylatoxin $\mathrm{C} 3 \mathrm{a}$ in human tenocytes. Mol Immunol 53:363-373. https://doi.org/10.1016/j.molimm. 2012.09.001
34. Asgari E, Le Friec G, Yamamoto H, Perucha E, Sacks SS, Köhl $\mathrm{J}$ et al (2013) C3a modulates IL-1 $\beta$ secretion in human monocytes by regulating ATP efflux and subsequent NLRP3 inflammasome activation. Blood 122:3473-3481. https://doi.org/10.1182/ blood-2013-05-502229

35. Schindler R, Gelfand JA, Dinarello CA (1990) Recombinant C5a stimulates transcription rather than translation of interleukin-1 (IL-1) and tumor necrosis factor: translational signal provided by lipopolysaccharide or IL-1 itself. Blood 76:1631-1638. https:// doi.org/10.1182/blood.V76.8.1631.1631

36. Hyc A, Osiecka-Iwan A, Strzelczyk P, Moskalewski S (2003) Effect of IL-1beta, TNF-alpha and IL-4 on complement regulatory protein mRNA expression in human articular chondrocytes. Int J Mol Med 11:91-94. https://doi.org/10.3892/ijmm.11.1.91

37. Terai I, Kobayashi K, Matsushita M, Fujita T, Matsuno K (1995) $\alpha 2$-Macroglobulin binds to and inhibits mannose-binding proteinassociated serine protease. Int Immunol 7:1579-1584. https://doi. org/10.1093/intimm/7.10.1579

38. Borth W, Urbanski A, Prohaska R, Susanj M, Luger TA (1990) Binding of recombinant interleukin- $1 \beta$ to the third complement component and $\alpha 2$-macroglobulin after activation of serum by immune complexes. Blood 75:2388-2395. https://doi.org/10. 1182/blood.V75.12.2388.2388

39. Huber-Lang M, Denk S, Fulda S, Erler E, Kalbitz M, Weckbach $S$ et al (2012) Cathepsin D is released after severe tissue trauma in vivo and is capable of generating C5a in vitro. Mol Immunol 50:60-65. https://doi.org/10.1016/j.molimm.2011.12.005

40. Handley CJ, Mok MT, Ilic MZ, Adcocks C, Buttle DJ, Robinson HC (2001) Cathepsin D cleaves aggrecan at unique sites within the interglobular domain and chondroitin sulfate attachment regions that are also cleaved when cartilage is maintained at acid pH. Matrix Biol 20:543-553. https://doi.org/10.1016/s0945053x(01)00168-8

41. Riegger J, Huber-Lang M, Brenner RE (2020) Crucial role of the terminal complement complex in chondrocyte death and hypertrophy after cartilage trauma. Osteoarthr Cartil 28:685-697. https:// doi.org/10.1016/j.joca.2020.01.004

42. Wang Q, Rozelle AL, Lepus CM, Scanzello CR, Song JJ, Larsen DM et al (2011) Identification of a central role for complement in osteoarthritis. Nat Med 17:1674-1679. https://doi.org/10.1038/ nm. 2543

Publisher's Note Springer Nature remains neutral with regard to jurisdictional claims in published maps and institutional affiliations. 